Birlesik Dünya Arastırma

BD-CENTER

Innovasyon ve Yayıneılık Merkezi

\section{Global Journal of Arts Education}

Volume 10, Issue 1, (2020) 93-102

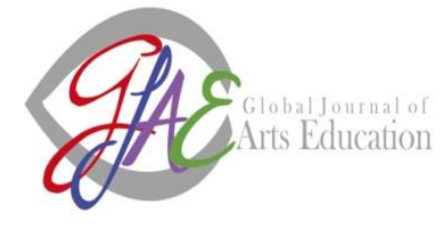

$\underline{\text { www.gjae.eu }}$

\title{
Childhood homes of interior architects in Turkey
}

Merve Celebi, Izmir University of Economics, Faculty of Fine Arts and Design, Department of Interior Architecture and Environmental Design, Sakarya Cad. 156, 35330, Balcova, Izmir, Turkey

Deniz Hasirci*, Faculty of Fine Arts and Design Interior Architecture and Environmental Design, Izmir University of Economics, Fevzi Cakmak, Sakarya Cd. No:156, 35330 Izmir, Turkey

\section{Suggested Citation:}

Celebi, M. \& Hasirci, D. (2020). Childhood homes of interior architects in Turkey. Global Journal of Arts Education. 10(1), 93-102. https://doi.org/10.18844/gjae.v10i1.5331

Received October 20, 2019; revised December 5, 2019; accepted February 26, 2020.

Selection and peer review under responsibility of Prof. Dr. Ayse Cakir Ilhan, Ankara University, Turkey.

${ }^{\circ} 2020$ Birlesik Dunya Yenilik Arastirma ve Yayincilik Merkezi. All rights reserved.

\begin{abstract}
The design of home interiors is important for an individual, especially in childhood, when one's character and psychological development is in progress. In this study, the aim is to explore the social and physical aspects of childhood homes of interior architects and their effects on their professional lives, and to understand the possible reflections of these special places on their current designs. Within this framework, the study was conducted with eight internationally recognised Turkish interior architects, with online interviews and sketchbooks, depending on the memories of the participants' childhood homes, and data were obtained regarding the interpretation of these special places, as well as their influence on their current design approaches and productions. Findings included understanding which aspects of the participants' homes were conveyed to their current productions in terms of preferences, approach and style. The results have implications on the interior architecture profession as well as interior architecture education.
\end{abstract}

Keywords: Childhood home environment, Turkish interior architects.

\footnotetext{
* ADDRESS FOR CORRESPONDENCE: Deniz Hasirci, Faculty of Fine Arts and Design Interior Architecture and Environmental, Izmir University of Economics, Fevzi Cakmak, Sakarya Cd. No:156, 35330 Izmir, Turkey.

E-mail address: deniz.hasirci@izmirekonomi.edu.tr
} 


\section{Introduction}

Homes provide us with a physical shelter, but also act as a spiritual environment. Memories of childhood homes play an increasing role in who we are today. Childhood homes and nostalgic longings are very directive emotions in recreating present home environments or projecting ideal home situations in the future (Cieraad, 1999). There is much to learn from these special environments to be conveyed into interior architecture education. The continuous intimate relationship between people and buildings (Goldberger, 2009) is at its peak when we think of children and their relationship with their homes as it acts as their first universe (Bachelard, 1994). The quality of home environments and their impact on child development and adulthood have been studied extensively (Evans, 2006; Leventhal, Selner-O'hagan, Brooks-Gunn, Bingenheimer \& Earls, 2004; Rodrigues, Saraiva \& Gabbard, 2005). However, there are limited sources on the effects of childhood home interiors on designers of homes - interior architects - and whether they convey features of these spaces into the interiors they create in their professional lives. This is believed to help understand which social and physical features of the home environment are most influential. As interior architects, the participants were expected to describe and represent their childhood home influences in words and more effectively by sketches. Another aim is to create a profile of the contemporary successful Turkish interior architects, and to question the extent to which their childhood homes have been reflected in their current works. The interviews were personal and provided information on the design approaches of each designer. The sketchbooks were expressive and elaborate and included not only sketches, but also photographs and notes. Among the significant goals of the study are drawing attention to home interiors and how these environments affect people in general and children in particular. It is also expected to achieve certain criteria in designing a home especially when a child is going to be raised in that environment. This study endeavours to create awareness among designers of home environments that they are not only shaping a space, but more importantly shaping memories and souls. This knowledge is crucial for interior architecture education and lessons learned need to be transferred to future designers.

\section{Childhood home interiors}

The home has an emotional relationship with its users and constitutes a psychological importance, and it may be lived as an extension of oneself, of one's desires, feelings, hopes and actions (Cristoforetti, Gennai \& Rodeschini, 2011). Moreover, the design, spatial organisation and furnishing of domestic houses influence and inflict concepts and ideologies of the home (Mallet, 2004). Actually, the home can be evaluated as a familiar place inhabited by family, friends, things and belongings, where particular activities and relationships are lived. A house is a part of the material structure of society, whereas a home is a phenomenon made by its residents. For its residents, a house is a physical frame that they use and equip with their daily actions and social relationships; a special meaning is given that brings about the concept of home (Bech-Jorgensen, 1994). The home is a material and an affective space shaped by everyday practices, lived experiences, social relationships, memories and emotions (Rikkinen, 2000).

The childhood home gives initial shape to all later memory, and this may be because it is through learning to live in the home that children learn the 'habitus' of their culture, which is argued as a figure of the between: above all, between nature and culture, and also between consciousness and the body, self and other, mechanism and technology, determinism and freedom and even between memory and imagination (Casey 2001, p. 409). Starting with childhood, our explorations in and around the home allow us to develop a sense of self as individuals. For most children, the interior of the home and its environment are the first places of their experiences throughout their early years (Iltus, 2007). The cognitive stimulation in the child's easy home environment is positively associated with the child's cognitive attainment (Edwards, 1992). Moreover, children's self-perceived competence and the home environment stimulation are positively correlated (Lee, Super \& Harkness, 2003). Our first houses are the grounds of our first experiences, where we discover laws that are later applied to the world at large (Cooper-Marcus, 2006). 
Our memories of home will set a tone for the way we experience the new (Goldberger, 2009). Memories are spatial and people associate 'meaning' to material components through experience and imprint them spatially in memory. Hence, homes are collectors of memories and they receive their meanings through repetitive experiences. The first houses are the grounds of our first experiences. These experiences and discoveries in our childhood homes are applied all throughout our lives as our guidelines. These homes hold symbolic power as a formative dwelling place, a place of origin and return, a place from which we embark upon a journey (Mallet, 2004). The childhood home has a crucial role in the psychological and social development of an individual, irrespective of having positive or negative memories of the home (Manzo, 2003). For most people, the childhood home is the place for first getting in touch with who we are as distinct personalities. The home is a child's territory of exploration of their own space they occupy (Cooper-Marcus, 2006). Age, gender and the effects of particular environments determine a child's environmental behaviour and opinions (Kopec, 2006). Children experience places differently from adults. They use all their senses in interacting with and learning in a physical environment. This multi-sensory experience combined with the complexity of the home environment creates a need for an analysis of homes as developmental settings with farreaching reflections to today (Iltus, 2007).

\section{Design of the study}

Eight actively practicing interior architects in Turkey were chosen for in-depth research, according to their age, productivity and recognition on national and international design platforms.

\subsection{Methods}

This study utilises two methods of data collection: interviews with the participants and the sketchbooks, which were filled with illustrations, notes and visuals of their childhood home environments, which would support the interviews. For this study, internet-based interviews were conducted and all interviews were recorded. The internet-based interviews provide a natural and comfortable feeling for both the interviewee and the participant, as being physically present can prompt feelings of self-consciousness (Miller \& Sinanan, 2014). Sketchbooks were sent to the participants to be used in a scrapbook format to allow flexibility in the participants' representations on paper. As the participants were interior architects, sketching was accepted to be a part of their profession and a way of their daily routine in thinking and expressing their ideas.

\subsection{Participants of the study}

Out of the participants, the oldest participant was born in 1969 and the youngest in 1981. Therefore, they were children in the 1970s and 1980s. The participant interior architects are listed below according to the dates of the interviews:

Nazar Sigaher: Born in Istanbul in 1981 and resides in Istanbul.

Emre Evrenos: Born in Istanbul in 1977 and resides in Istanbul.

Onur Karlidag: Born in Samsun in 1978 and resides in Ankara.

Bersun Erturk: Born in Eskisehir in 1980 and resides in Dubai, UAE.

Engin Oncuoglu: Born in Ankara in 1972 and resides in Ankara.

Yalin Tan: Born in Izmir in 1969 and resides in Istanbul.

Durul Onaran: Born in Izmir in 1972 and resides in Ankara.

Levent Tumer: Born in Ankara in 1972 and resides in Ankara. 


\subsection{Interviews and sketchbooks: results and discussion}

The interviews were realised in Turkish and lasted from 35 to 45 minutes, and the participants discussed their sketchbooks.

\subsubsection{Question 1: can you describe the physical environment of your childhood home?}

While many of the participants lived in many different homes or lived in only one home and then moved, Sigaher was still living in his childhood home. The building of his home was built in the 1960s or late 1950s, reflecting the era's style. Evrenos' first home was an army-housing unit that was a welldesigned large apartment receiving good daylight. Karlidag lived in two attached homes with different functions in his childhood. The first one was his grandparents' three-storey private modern building that was built in the 1970s. The other one was composed of stores and offices, where his father's architecture office was also located. The house was designed by his father, according to the 1970s style, which he called 'retro'. Erturk had to move many times in his childhood because of his father's profession. Out of eight different childhood homes, he was mostly influenced by the one in Kuwait. Unlike Turkish homes, it did not have an entrance or a hallway. Oncuoglu's childhood home was an apartment on the first floor, which had wide windows and built-in closets. For Tan, there is not only one image of home, but many, because his father, who was an interior architect, liked to change the interior of their home frequently. There was an acrylic relief on one of the walls, with strong graphic expressions, and a cubic coffee table with a sliding door, which was used either for storage of his toys or as a toy carriage. Onaran's childhood home apartment had two facades, one of which was facing the sea. It had a large living room that enabled the family to live together 'with the sea'. Tumer's childhood home was constructed in the late 1960s or early 1970s, reflecting the architecture of the era. It had modernist furniture reflecting the style of the time. In terms of geographic dispersion of the participants' childhood homes, two were in Istanbul, two were in Ankara, two were in Izmir, one was in Samsun and one was in Kuwait. The homes were constructed in the 1960s, 1970s or 1980s. Most reflected the era's style that was identified as 'modernist', 'retro' or 'eclectic' by the participants. Due to their profession, they all communicated the details of their furniture, materials, colours, circulation and the relationship of their home with its close surroundings, which sheds light on the time (Figure $1)$.

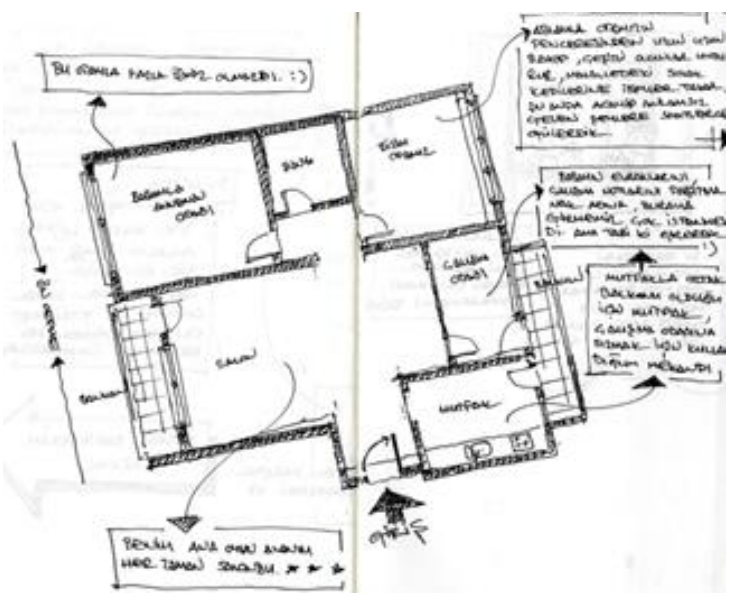

Figure 1. Evrenos' childhood home plan drawing, with two bedrooms and a workroom, signifying that the living room was his major playground

\subsubsection{Question 2: can you describe the social environment (family life) in your childhood home?}

In Sigaher's home, the furniture of the dining and living rooms were removed and the space was transformed into a playground for children when they were young. Listening to music and reading books were family rituals, and the library acted as a focal point in an intimate family life. There was art in their home at all times and he was fond of drawing comics. With his sister, as a family, they had 
positive relationships and a disciplined lifestyle. Karlidag had a lively and active home life in his childhood. It was a family of three with employees, customers and students, because of their café, workshop and office, which were all connected to each other. Except bedrooms, in other parts of the house, there was a flow of functions among spaces. Erturk's father was a civil engineer and his mother was a homemaker, and both were good at drawing. Oncuoglu identifies his family as a typical urbanising conservative Turkish family. His father was an architect and his mother was a homemaker. The living room was used all the time; the furniture was not covered with sheets to be opened only for guests, which was a custom in a typical Turkish home at the time. After his parents were separated, Tan had two different homes. His father was very interested in music and reading, so they had a large library, and meals were eaten in both the kitchen and the living room. Onaran had a typical Izmir family, having a working father and a homemaker mother. An open kitchen layout integrated with the living and dining space made it possible for the whole family to be together. Tumer's childhood home was a small and compact apartment. Technological devices were encased in furniture at that time, like their music system, which had wooden consoles, and television that was within a wooden case with shutters. Regarding the families of the participants, four had no siblings, three had one sibling and one of them had one sister and a twin brother. All of the participants were raised in an environment of culture, art and design, which contributed to their future lives (Figure 2).



Figure 2. Drawing of the workshop of Karlidag's mother who was an art teacher (Text: 'My mother's art atelier.')

\subsubsection{Question 3: which part of that house did you like most? Why?}

In Sigaher's home, the stove was a focal point as it radiated heat, giving an enjoyable fire view. Having high ceilings and good daylight, it used to raise the moods with the dinner table as a focal point in their home. Evrenos remembers his home receiving good quality daylight. He liked their modern modular furniture, which were durable and well-detailed. Karlidag had an active home life, shared with many different people. He mentions the special 1970s style with amorphous forms and Plexiglas lighting units as remarkable. The plan of Erturk's childhood home had effective solutions. He also remembers the 'futuristic' furniture of their home in Eskisehir, like the sofa and music system. Oncuoglu remembers particular interior design decisions like door casings, built-in cabinets and railings of the staircase that he used for playgrounds. Tan was very impressed by the acrylic relief on their wall and liked to play or draw in front of it a lot. When he talks about home, he remembers that relief. He thinks that even if a child has his own playroom, he or she likes to play in the living room to be with the rest of the family. For Onaran, the most important part of their home was a connected large and spacious living room, semi-open kitchen and the huge balcony. Tumer used to like their television that was like a piece of furniture with a wooden case and a shutter, the fireplace, the seating units and the lamp in their living room and the 'cozy' storage room at his childhood home. The aspects that the participants used to like in their childhood homes were directly related with pleasant memories. Living rooms, kitchens and staircases were important because these were places that they could socialise with family members or neighbours. Openings with large sills that enabled them to 
interact with the outside were places that they liked to spend their time. Playrooms are also remembered as special spaces of their homes (Figure 3).

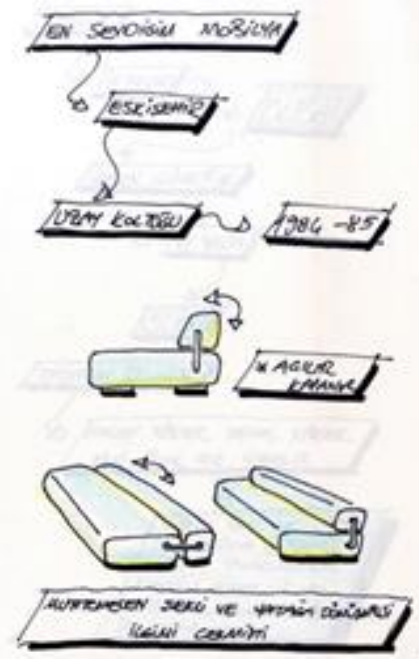

Figure 3. Drawings of Erturk's favourite furniture of his childhood, which was a futuristic seating unit transformable to a bed (Text: 'My favourite furniture piece $\rightarrow$ Eskisehir city $\rightarrow$ space seat $\rightarrow$ 1984-1985 $\rightarrow$ opening and closing $\rightarrow$ probably the shape and the fact that it turned into a bed caught my attention')

\subsubsection{Question 4: which part of the house did you dislike most? Why?}

Sigaher's home, like many apartments of its era, had a small kitchen that prevented two or more people to do something at the same time. Evrenos remembers the bedrooms of his childhood home as not having good daylight. Karlidag critiques the change of their 70s modern interior design into an over-decorated 80s style. Due to their 'nomadic' life, Erturk remembers having no long-lasting furniture in their homes. Oncuoglu remembers the heating problems and limited hot water of his childhood home. Tan does not remember anything that he disliked in his childhood home. Onaran remembers the long corridor and dark rooms as the most distasteful part of their home and Tumer did not like the building's steep and spiral staircase, because he found it dangerous as a child. What was disliked was related with negative features, such as dark corridors and bedrooms, steep and narrow staircases, which may activate the imagination of a child (Figure 4).

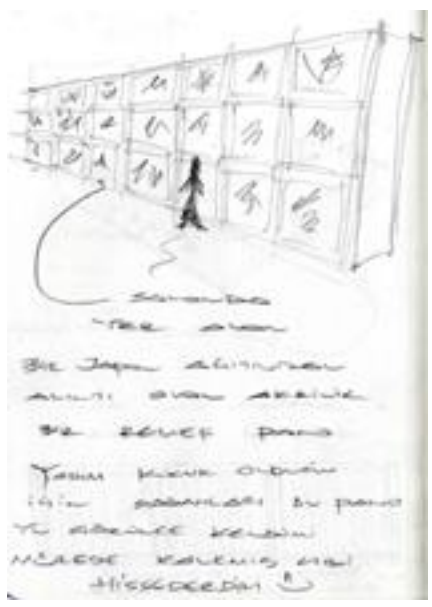

Figure 4. Drawing of Tan depicting himself as a child in front of the impressive relief in his childhood home (Text: 'The depiction of a Japanese requiem on an acrylic relief panel. When I wake up, I would feel as if I had woken up in a museum') 


\subsubsection{Question 5: as a successful interior architect of today, how would you reshape the interior of that house?}

Sigaher did not get involved with any large renovations in their apartment, and designed only the library and the television unit. Evrenos would like to increase privacy and integrate the interior parts of his childhood home. Karlidag thinks that his childhood home was carefully designed and functions of the house were fulfilled. Erturk stated that he would adapt built-in furniture, and design longlasting, quality furniture. Oncuoglu would choose items that would light up the interior and would never choose heavy furniture. He also would use fewer materials to have a calmer interior. As Tan's father was an interior architect, their home was a designed with careful consideration. Onaran finds it challenging to reshape the dark corridor in their apartment in terms of usage of new technologies and imagination in order to illuminate it with daylight or lighting fixtures. Finally, Tumer would reshape it with the respective era's architectural elements, like upholstery or colours. The participants expressed how they would change the interiors of their childhood home interiors according to what they remember as problematic or distasteful. In terms of furniture, they would use less, lighter furniture and would apply built-in furniture if applicable. They would increase privacy from outside and integrity inside by having minimum walls or applying flexible partitions. By using new technologies, they would increase the reception of daylight at home and use more creative artificial lights to get rid of dark places. Moreover, they will have more and larger wet spaces.

\subsubsection{Question 6: name three key experiences in your childhood home that you think have shaped the language of your design today. How?}

In Sigaher's childhood home, a problematic plan layout brings disadvantages for the users. The circulation to other rooms was not solved. Evrenos used to like reading comic books. The table was the place for his creative works, which was always full of drawing and painting pencils. Karlidag was influenced by his architect father, and being raised in a modernist environment influenced him. Erturk recalls large windows, which were letting the daylight in. According to Oncuoglu, discovering special places that would fit the childhood needs and to have a feeling of belonging and place attachment is crucial; like the niches and the built-in cabinets. Tan's approach to material use and comprehensive design is quite similar. Onaran developed a functional and simple design understanding. Their home was very minimalist, simple and functional. Today, he is following the same movement where functionality is a priority in his designs. Tumer thinks that the style of his childhood home furniture affected him in terms of his perceptions towards becoming an interior architect and furniture design. The participants responded to that question by giving examples of positive or negative experiences. Positive experiences include special and personal spaces, large windows, created playgrounds, place attachment, functionality and connection with furniture. Negative experiences include difficult plan layouts, insufficient illumination and unsuccessful material combinations and applications (Figures 5 and 6).

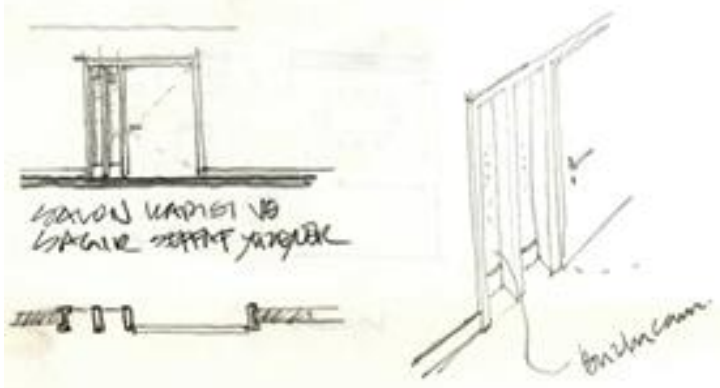

Figure 5. Elevation, section and isometric drawings of Oncuoglu's childhood home's living room door, which was used as a playground for him (Text: 'The living room door and blank transparent surfaces. Translucent glass.') 


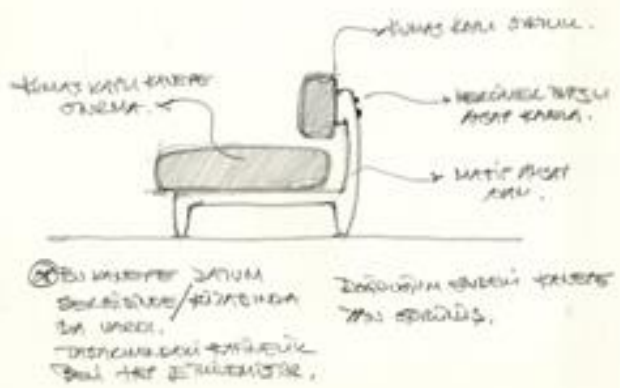

Figure 6. Drawing of a chair at Tumer's childhood home which influenced him with its refined design (Text: Clockwise from top: 'Upholstered backing, lentil head wooden dowel, hardwood legs and upholstered seating. This sofa was also in the DATUMM (Ultav, Hasirci, Borvali \& Atmaca, 2015) exhibition/ book. Side view of the sofa in the house I was born in.')

\subsubsection{Question 7: how do you think this part of your life in that house affected your design language of today?}

Sigaher thinks that living conditions direct and give characteristic to one's design. His intellectual family environment with different interests may not influence his design; however, it definitely contributed to his success in his professional life. Evrenos thinks that he was visually affected by comic books and illustrated encyclopaedias of animals and space. These books contributed to his drawing skills. Experiencing architecture and art affected Karlidag in his early ages. He believes he became an interior architect because of that childhood environment. Playing and creating spaces with interlocking building blocks played a role in Erturk's understanding of the relationships between interior elements. Oncuoglu's childhood home did not have an architectural identity; hence, he finds his childhood home architecturally insignificant. Tan's father's 'genius' solutions of small volumes, as well as his fathers' sketches, s continue to affect him subconsciously. Onaran has a tendency to design a library in living rooms, large kitchens and living rooms in his designs today. Tumer thinks that besides his childhood home and its furniture, his father who was an architect has affected him as a designer. Today, he is careful about details in his designs, the composition of the space, and use of built-in or mobile furniture, like his father. With the answers given to this question, living conditions, intellectual family environment, exposure to visuals or drawings and playing and interacting at home have an impact on the participants. Participants clearly mentioned that they were affected by good interior solutions and designed furniture, and that they give priority to functionality and simplicity.

\subsubsection{Question 8: can you name any sort of similarities between your childhood home and the interiors you design today?}

Sigaher finds no similarities between his childhood home and the interiors he designs today, although he transfers his background. Regarding the similarities between what the participants design today and their childhood home environments, Evrenos believes that there should be a special spot or furniture in every project like in his childhood home, according to needs and references of the users. Karlidag does not believe that there is a direct relationship between his childhood home and the interiors he designs today. However, he believes that there is a style for every designer affected by their background. Although it is difficult to control, Erturk still tries to let the daylight in his interiors and enjoys high ceilings and large windows in his designs. Oncuoglu compares the scales of his childhood home with his projects of today. Tan believes that a person has a base or a background from his childhood which flourishes. Onaran believes a large living room and an integrated large open or semi-open kitchen are indispensable to a home. Tumer also applies the functionality of his childhood home to his own designs today. 


\subsubsection{Question 9: what aspects of the design language of your home today are inspired by your childhood and childhood home?}

As Sigaher still lives in his childhood home, this question is not applicable to him. Evrenos is living in his grandmother's apartment in Istanbul which has large windows like in his childhood home, enabling the family members to interact with the outside. Karlidag finds the design language of his current home and his childhood home very similar - modernist and minimalist. Erturk is still wandering and having a nomad life like in his childhood. Due to various materials in Oncuoglu's home, today the use of materials is kept to a minimum. Tan prefers calm and light colors in his own home interior, in contrast to his childhood homes, which were all in dark colours. Onaran has a very similar interior design and lifestyle in his home today with his childhood home where all family members can be together, sharing the same space. In Tumer's home today, he designed all the spaces according to its functions, where circulations and dead spaces were kept at a minimum, just like in his childhood home.

\section{Conclusion and recommendations}

This study tries to highlight the meaning of home with different perspectives, focusing on childhood home environments and its effects on interior architects' spatial designs today. The participants showed real enthusiasm in talking about their childhood and their home life during that time of their lives. Bringing these memories into light and having a chance to share them with someone who was also eager to listen, was enjoyable for them. In this study, the effects of childhood home environments on designs of interior architects were demonstrated, with social and physical messages being carried throughout their later lives. Lifestyles of the families, profession of the parents, interrelations among family members, sharing the same room and playing with brothers and sisters, relationships with the neighbours, experiencing surroundings within homes were important factors for the participants. Common interior architectural considerations like reception of good daylight, good interior plan layout, circulation solutions, styles of the respective era furniture, equipment, objects, colours, textures and relationships with their close surroundings of their homes were issues that they valued. Positive memories like playing or socialising at home were the most valuable experiences. Shared spaces like living room, kitchen, staircase or a special corner of a room that would enable them to interact with other members of their family contributed to this, and connections to the outside were significant. There is more to be done regarding the interior architecture of houses focusing on these special places, and finding out alternative design solutions for better living. Although online interviews had several benefits, face-to-face interviews may be used in the future on location.

The term nostalgia is derived from the Greek 'nostos' for return home and 'algos' for pain. Hence, it implies homesickness and a yearning for home (Blunt, 2003; Chambers, 1990). Therefore, 'interpreting nostalgia' with interior architects in this study not only brought about the vivid memories of their childhood homes, but also gave them a chance to face the effects of these very precious places on their designs of today, even after decades. Although a home 'may lack solutions to a great many of its occupants' ills, its rooms nevertheless give evidence of a happiness to which architecture has made its distinctive contribution' (De Botton, 2006, p. 11). This significant message needs to be integrated in interior architecture education so that graduates understand that designing a home is a big responsibility, especially since it is where the first memories of a life are shaped, and that, in turn, has the power to shape future life preferences.

\section{References}

Bachelard, G. (1994). The poetics of space. (M. Jolas, Trans.). Boston, MA: Beacon. Bech-Jorgensen, B. (1994). When every day becomes everyday. Kobenhavn, Denmark: Akademisk Forlag. Blunt, A. (2003). Collective memory and productive nostalgia: Anglo-Indian homemaking at McCluskieganj. Environment and Planning D: Society and Space, 21(6), 717-738. doi:10.1068\%2Fd327 
Casey, E. S. (2001). Body, self and landscape: a geophilosophical inquiry into the place-world. In P. C. Adams, S. D. Hoelscher \& K. E. Till (Eds.), Textures of place: exploring humanist geographies (pp. 403-425). Minneapolis, MN: University of Minnesota Press. Retrieved from https://www.jstor.org/stable/ 10.5749/j.cttttg77

Chambers, I. (1990). Border dialogues. London, UK: Routledge.

Cieraad, I. (1999). Introduction: anthropology at home. In I. Cieraad (Ed.), At home: an anthropology of domestic space. (pp. 1-12). New York, NY: Syracuse University Press. Retrieved from https://www. researchgate.net/publication/326462226_Introduction_Anthropology_at_Home

Cooper-Marcus, C. (2006). House as a mirror of self: exploring the deeper meaning of home. Like Worth, $\mathrm{FL}:$ Nicolas-Hays, Inc.

Cristoforetti, A., Gennai, F. \& Rodeschini, G. (2011). Home sweet home: the emotional construction of places. Journal of Aging Studies, 25, 225-232. doi:10.1016/j.jaging.2011.03.006

De Botton, A. (2006). The architecture of happiness. London, UK: Penguin Group.

Edwards, S. (1992). Early environment and mothers intellectual ability affect cognitive attainment of adolescents' children. Family Planning Perspectives, 24(2), 89-91. Retrieved from https://search. proquest.com/openview/3273ac08fe749411c69be17f26b8f375/1?pq-origsite=gscholar\&cbl=27515

Evans, G. W. (2006). Child development and the physical environment. Annual Review of Psychology, 57(1), 423451. doi:10.1146/annurev.psych.57.102904.190057

Goldberger, P. (2009). Why architecture matters. New Haven, CT: Yale University Press.

Iltus, S. (2007). Significance of home environments as proxy indicators for early childhood care and education. Paper commissioned for the EFA Global Monitoring Report. Retrieved from https://pdfs. semanticscholar.org/abe3/b52ea62242891352f7f7231f4db81b48f827.pdf

Kopec, D. (2006). Environmental psychology for design. New York, NY: Fairchild Publications.

Lee, J., Super, C. M. \& Harkness, S. (2003). Self-perception of competence in Korean children: age, sex and home influences. Asian Journal of Social Psychology, 6(2), 133-147. doi:10.1111/1467-839X.t01-1-00016

Leventhal, T., Selner-O'hagan, M., Brooks-Gunn, J., Bingenheimer, J. \& Earls, F. (2004). The homelife interview from the project on human development in Chicago neighborhoods: assessment of parenting and home environment for 3- to 15-year-olds. Parenting: Science and Practice, 4(2/3), 211-241. doi:10.1080/ 15295192.2004.9681271

Mallet, S. (2004). Understanding home: a critical review of the literature. Sociological Review, 52(1), 62-89. doi:10.1111\%2Fj.1467-954X.2004.00442.x

Manzo, L. C. (2003). Beyond house and haven: towards a revisiting of emotional relationships with places. Journal of Environmental Psychology, 23, 47-61. doi:10.1016/S0272-4944(02)00074-9

Miller, D. \& Sinanan, J. (2014). Webcam. Cambridge, UK: Polity.

Rikkinen, H. (2000). Children's life-worlds. In M. Robertson \& R. Gerber (Eds.), The child's world: triggers for learning (pp. 87-108). Melbourne, Australia: Shannon Books Australia Pty Ltd.

Rodrigues, L., Saraiva, L. \& Gabbard, C. (2005). Development and construct validation of an inventory for assessing the home environment for motor development. Research Quarterly for Exercise and Sport, 76(2), 140. doi:10.1080/02701367.2005.10599276 